THURSDAY, MARCH 2, 1876

\section{THE GOVERNMENT SCHEME OF UNIVERSITY REFORM}

$T$ HE speech of Lord Salisbury in the House of Lords 1 on Thursday evening, on introducing a Bill for regulating the reform of Oxford University, will probably satisfy the expectations with which the declaration of the Government policy has been awaited. it is a fortunate circumstance that the condact of the measure should be placed in the hands of one who is, at the same time, Chancellor of the University, a minister in whom both his party and the country have entire confidence, and also a well-known friend of the physical sciences. The Government scheme, therefore, is introduced under favourable auspices; and, in itself, so far as it has been yet revealed, it seems calculated to disarm all opposition. It is true that much yet remains to be learned concerning the modes in which the scheme is to operate. The names of the Commissioners, to whom a certain degree of control is apparently to be entrusted, will be looked for with anxiety; and the details, which will only be understood when the bill is printed, will also be of much interest to those who will be directly affected by them. But the general public, who are after all the party most concerned, is contented with the enunciation of principles which Lord Salisbury's speech contains. He argued, with great ingenuity, that it is not possible for Parliament to dictate to the University and College authorities the precise lines of reorganisation along which they are to proceed. This argument suggests much that a party critic may object to as involving an abnegation on the part of Ministers of their own proper responsibility. However that may be, it is certain that people at large are totally incapable of giving an intelligent approval to anything more definite than the proposals which Lord Salisbury has sketched. Indeed, it may be doubted whether the absence of complete knowledge to which Lord Salisbury himself pleaded guilty, though it may somewhat surprise and disturb Oxford residents, will not have the effect of bringing him into closer harmony with the general feeling of the country. The case for reform does not rest upon minor matters of detail which require research to discover and particular experience to appreciate, and of which the meaning might be altogether altered by further research and wider experience. The plain statement of the facts is enough, and upon that plain statement Lord Salisbury has wisely relied.

The collective revenue of the Oxford Colleges, after making certain necessary deductions, amounts to something over 200,000l. per annum; and as the number of undergraduates is less than 1,000 , it follows that the average income per undergraduate is a little more than 200l. a year. It is important that this estimate should not be interpreted as if it meant the average cost of educating each undergraduate, as Lord Salisbury has not sufficiently guarded himself against the possibility of this confusion. The real meaning of the calculation is to indicate forcibly that at the present time endowment is out of all proportion to educational efficiency. Looking at the figures from another point of view, we find that,

VoL. XIII.-No. 33I out of the total endowments, Fellowships of one kind or another take just one-half or 100,00ol. Of this sum, again, Lord Salisbury estimates that "idle Fellowships," or those to which no duties are attached, absorb from one-half to four-fifths. There is thus left a balance of from 50,000l. to $80,000 \%$, a year, which is admittedly not devoted to academical purposes. It is important to recollect that this calculation comes to us upon the authority of Lord Salisbury. The late University Commission, rigidly limiting itself to its immediate functions, merely presented a general account of the income and expenditure of the Universities and their Colleges, and did not attempt to estimate the number of non-resident Fellows, or even to suggest what proportion of the endowments were unremuneratively expended. But this large sum is far from being all that University reformers will have to deal with. Lord Salisbury states that there must be added no less than $123,000 l$. per annum, which represents the probable augmentation in the rents of the College estates within the next fifteen years, as ascertained by the Commission of Inquiry presided over by the Duke of Cleveland. A yet further addition is suggested by Lord Salisbury, arising from the appropriation to educational purposes of certain ancient trust-funds vested in the Colleges, which are now misapplied. Of the amount of this latter source of income, it is impossible to give even an approximate guess. Lord Salisbury carefully refrained from hinting at any specific trust; and it is doubtful whether there are, at Oxford at least, any misapplied trust-funds of any magnitude, except perhaps the Hulsean endowment connected with Brasenose College. Lord Salisbury seems rather to have been glad to take the opportunity of stating his views with regard to the general question of modifying old endowments, than to have referred to any changes of practical importance. It is noteworthy, however, that his views entirely coincide with those expressed by Lord Derby before the University of Edinburgh last December; and thus the two most influential members of the Conservative Ministry are found in agreement upon a policy which has sometimes been claimed as the peculiar heritage of the Liberal party. Whatever may come from minor trusts, the whole available surplus of the endowments at Oxford may be fairly estimated at about 200,000l. a year. This sum, of course, is not at the present moment ready for distribution; but it is the amount which, allowing for vested interests and the slow processes of change, Lord Salisbury appropriates to the purposes of his scheme of reform.

That scheme itself has only, as yet, been indicated with very vague touches; but enough has been said to satisfy all reasonable hopes, and to encourage us to wait confidently for the filling-in of the details. In the first place, Lord Salisbury proposes to restore to the University, so far as money can do so, her ancient pre-eminence over the Colleges. The demands of the University for buildings and for professors are to be supplied out of the forfeited "idle Fellowships." "It may be wise to maintain a few of these latter, limiting the holding of them to a certain number of years; but I do venture to lay down that all the University wants, in the shape of museums, libraries, lecture-rooms, and the proper payment of teachers, should be provided for, before the subject of furnishing incomes to men who do nothing can be enter- 
tained." The second principle enunciated by Lord Salisbury is the endowment of research-a principle which has been long advocated in these columns, but which now for the first time appears destined to obtain legislative sanction. In the case of its distinguished sojourner, Prof. Max Müller, the University of Oxford has already admitted its duties in this matter; and now research in the physical sciences, under the ægis of Lord Salisbury, and with all the authority that Parliament can lend, will put in its claim to be "made a part of the regular and recognised machinery of the University." To many persons this will be thought the greatest novelty contained in the speech, and it is significant that none of the three peers who followed the mover made any allusion to it in their brief remarks. But it is not necessary now to expatiate upon the importance of the proposal, or the valuable results that will flow from it. It is the first fruits of the Royal Commission on the Advancement of Science, and will lead, we trust, to the adoption of more of the recommendations made by that laborious body. It is of more importance on this occasion to call attention to a distinction which Lord Salisbury has apparently drawn, and to which the Colleges would do well to take heed. If we understand his words aright, he would impose upon the University the duty of supplying, of course from the College endowments, the capital sum that will be required "from time to time for buildings and apparatus, necessary for the purposes of research;" while he would leave to the individual colleges "to provide for the maintenance and benefit of persons of known ability and learning, who may be engaged in study or research in the realms of art and science." This distinction seems to us an important one, partly because it assigns to each the functions which they can best perform, with the least revolution in their characters; and still more because it insists upon two separate modes of endowing research, which are of equal value, and must be both demanded alike. We cannot forbear quoting at some length the comprehensive views of Lord Salisbury on this subject:-"We are of opinion that the mere duty of communicating knowledge to others does not fulfil all the functions of a University, and that the best Universities in former times have been those in which the instructors, in addition to imparting learning, were engaged in adding new stores to the already acquired accumulation of knowledge. There are new sciences which have gained, and which are pressing for, admission to the Universities, and I chink no one can doubt that it is for the interest alike of the students and of the nation at large that such sciences should have full encouragement. . . . What I am particularly anxious for is that all branches of culture should have equal encouragement, and should be regarded, not as rivals, but as allies in the great and difficult task of cultivating and developing the human mind." Apart from these two leading features of the Government scheme of University Reform-the endowment of the University by the Colleges, and the endowment of Research-it remains only to notice the ease with which Lord Salisbury, in one short sentence, brushes aside "the religious difficulty" as unworthy of attention. "The teachers at Oxford are not clergymen now, and if we want to get the best men, we must get them from other sources than that which formerly supplied them."

With regard to the machinery by which these great reforms are to be effected, it is better that criticism should wait until fuller explanation is given. On a first glance, it would seem that the colleges are to be allowed a year and a half to devise their own schemes of reform, subject only to the approval of the Commissioners. On this point we confess to a feeling of distrust of such "permissive legislation;" and are disposed to adhere to the old-fashioned liberal theory, which had its advocate in the Archbishop of Canterbury. "He believed that the Colleges are not an exception to the general rule which has been found to exist everywhere, that hardly any cor. poration was capable of entirely reforming itself without external pressure." It should never be forgotten that some colleges have already tried their hands at reform, and that none have yet made adequate provision for the wants of the University or of scientific research. The College which, in all educational matters, is usually re. cognised as the most efficient, has obtained final sanction to a scheme which does not allude to either of these subjects. Another college imagined but a few years ago that it was reorganising itself in accordance with the most modern ideal, when its teaching staff obtained permission from their episcopal visitor that they might one and all incontinently marry, and bought off his natural opposition by agreeing to retain all the existing clerical restrictions. It is whispered, at the present moment, that a third college has just matured a scheme by which each of the tutors shall receive a fixed salary from endow. ment of $800 \%$. per annum. With these instances in view, it will manifestly be the duty of all sincere reformers to urge that the powers given to the Commissioners should be strong enough to override the possibility of such abuses. If only this be done, and if the name of Cambridge be added to the bill, the Government project will become in all respects praiseworthy.

\section{LEGISLATION REGARDING VIVISECTION}

$T \mathrm{~N}$ our observations last week upon the Report of the 1 Vivisection Commission, we remarked that some might be inclined to think that in the legislative measures recommended Science has made too great concessions to popular feeling, and a more careful perusal of this bulky volume tends to convince us of the correctness of this opinion. One of the most astonishing things referred to in the whole report is the small number of persons for whose restraint the new law is to be passed. Judging from some of the statements made by opponents of vivisection, one would think the vivisectors in this country must be counted by hundreds ; but the Commis. sioners inform us that, on the contrary, not more than fifteen to twenty at the utmost are systematically engaged in the performance of experiments on living animals. They add, however, that experiments are, there is little doubt, occasionally performed by private persons, of whose number they can form no accurate computation. As there might be many such, and their experiments taken collectively might give good grounds for the belief that vivisection is extensively carried on in this country, we have tried to gain some information on this point from the statements of various witnesses. The Society for the Protection of Animals liable to Vivisection has published a pamphlet containing such extracts from the Report of 